\title{
РЕФЛЕКСИВНОСТЬ И ЭМПАТИЙНОСТЬ В СТРУКТУРЕ СОЦИАЛЬНОЙ КОМПЕТЕНТНОСТИ ПСИХОЛОГОВ
}

\section{Твердоступ К.Г.}

Государственное бюджетное образовательное учреждение дополнительного профессионального образования «Крымский республиканский институт постдипломного педагогического образования», г. Симферополь, Республика Крым, Российская Федерация

В данной статье предъявлена значимость вопросов определения социальных компетенций психологов в рамках компетентностного подхода. Представлен краткий анализ дефиниций «компетеничя», «компетентность», "социальная компетентность», описаны составляющие сочиальной компетентности психологов. Предложена попытка представления рефлексивности и эмпатийности как содержательных элементов в структуре социильной компетентности педагога-психолога.

Ключевые слова: рефлексивность; эмпатийность; сочиальная компетентность; компетенция; компетентностный подход; психолог.

\section{REFLEXIVITY AND EMPATHY IN THE STRUCTURE OF THE SOCIAL COMPETENCE OF PSYCHOLOGISTS}

\section{Tverdostup K.G.}

Crimean Republican Institute of Postgraduate Pedagogical Education, Simferopol, Republic of Crimea, Russian Federation

The article focuses upon the importance of determining the social competencies of psychologists in the context of the competency building approach. A brief analysis of such definitions as "competency", "competence", "social competence" is presented, the components of the so- 
cial competence of psychologists are described. An attempt to represent reflexivity and empathy as meaningful elements in the structure of the social competence of a teacher-psychologist is proposed.

Keywords: reflexivity; empathy; social competence; competency; competency building approach; psychologist.

\section{Постановка проблемы}

Переход отечественной системы высшего профессионального образования на ФГОС ВПО третьего поколения, базирующегося на методологии компетентностного подхода, ставит задачу определения и формирования профессиональных компетенций специалиста, занятого в сфере образования. В отличие от традиционной оценки качества подготовки специалистов, базирующейся на используемых в образовательных стандартах терминах «знания», «умения», «навыки», компетентностный подход, заявленный в ФГОС третьего поколения, при описании образа специалиста оперирует понятиями «компетентность» и «компетенции», направлен на обеспечение «условий создания общественной ситуации развития обучающихся, обеспечивающей их социальную самоидентификацию посредством личностно значимой деятельности» [4].

Известно, что основу для выделения профессиональных компетенций любого специалиста составляет функциональная структура конкретного вида профессиональной деятельности. Профессиональная компетентность психолога проявляется в творческом характере его деятельности, в активном поиске новаторских подходов и инновационных технологий, личной инициативе и профессиональной коммуникабельности [4].

С целью оценки образовательной среды и уровня развития компетенции у выпускников психологических факультетов, а также определения компетентности психологов-практиков, их профессиональных обязанностей, в Российской Федерации приняты профстандарты, где представлен перечень необходимых для выполнения трудовых действий психолога компетенций, определено их соответствие требованиям профессионального стандарта [4]. 
Обобщение требований к психологам в соответствии с профстандартом, показало, что профессионализм психолога обуславливается сформированностью: общего и социального интеллекта, психологических знаний, умений и навыков, владение специальным и личностным психологическим инструментарием, присутствием таких специальных способностей и индивидуально-психологических характеристик, как стрессоустойчивость, самоконтроль, уверенность в себе, высокая адаптивность, коммуникативность, эмпатийность, умение конструктивно преодолевать конфликты, склонность к саморазвитию, иными словами, социальной компетентностью [4].

Именно социальной компетентности как сложному и интегративному качеству личности, как готовности и способности к социальному взаимодействию в разных жизненных сферах, как единству социальной адаптированности и мобильности, многими современными исследователями (Е.В. Каменская, Л.Ш. Каримова, А.В. Хуторский и др.) уделено значительное место в структуре ключевых компетентностей психолога.

В основных характеристиках профстандарта, предъявляемых к психологу, указывается на социабельность, великодушие, тактичность, дипломатичность, эмпатийность, проницательность, рассудительность, рефлексивность. Таким образом, особую значимость для реализации профессиональной деятельности психолога представляют такие содержательные элементы социальной компетентности, как развитая эмпатия и рефлексия.

Ввиду того, что научная проработка проблемы компетенций психолога в настоящее время не завершена, научный интерес представляет исследовательская работа в направлении изучения рефлексивности и эмпатийности как составляющих социальной компетентности психолога, определяющих его эффективность и профессионализм.

В связи с этим, цель статьи - изучить и описать значимость рефлексивности и эмпатийности в структуре социальной компетентности психологов. 


\section{Основное изложение материала}

Компетентностный подход в обучении возник как альтернатива практико-ориентированных качеств, необходимых обучающимся в социальной жизни и профессиональной деятельности, абстрактно-теоретическим знаниям. В свою очередь, научная дискуссия развернулась между отечественными и зарубежными учеными по вопросам сущности понятий «компетенция» и «компетентность», «социальная компетентность». В итоге, пришли к необходимости разграничивать дефиниции «компетенция» и «компетентность».

Относительно трактовок понятия «компетентность», можно отметить общий значительный вклад в разработку вопросов компетентности именно отечественных исследователей, таких как А.В. Дахин, И.А. Зимняя, А.К. Маркова, В.Г. Первутинский, А.В. Хуторский. По мысли отечественного психолога И.А. Зимней, «компетенция/ компетентность - это интегральный социально-личностно-поведенческий феномен, результат образования в совокупности мотивационно-ценностных, когнитивных составляющих» [1, с. 35].

Таким образом, «компетенция» понимается как обобщенная характеристика личности, определяющая готовность к успешному решению профессиональных и социально-личностных задач. «Компетентность» как персонифицированная компетенция, выраженная способность применять знания, умения, опыт, личностные качества для решения профессиональных, социальных и индивидуально значимых задач.

Вслед за И.А. Зимней, Е.В. Овчаровой, «социальная компетентность» представляется нами как вид профессиональной компетентности, как индивидуально-психологическое, интегративное качество, формирующееся и проявляющееся по ходу решения специалистом стандартных и нестандартных задач, адекватных всему разнообразию социальных и профессиональных ситуаций.

Для того, чтобы эффективно организовать развитие компетенций в рамках компетентностного подхода, важно понимать их взаимовлияние друг на друга, определить значимость каждой, последовательность их развития, выделить предметные области, ответственные за формирование тех или иных компетенций, составить модели ком- 
петенций и модели развития компетенций с учетом формирующих их детерминант.

В рамках статьи нет необходимости останавливаться на подробном описании содержания ведущих компетенций профессиональной деятельности психолога. Отметим, что одной из базовых компетенций психолога является наличие определенной базы профессиональных знаний, умений и навыков (ЗУНов) и обладание развитой социальной компетентностью.

В результате обобщения материалов исследований А.Г. Асмолова, И.А. Зимней, А.Т. Калиевой, Л. Ш. Каримовой, В.Г. Первутинского, можно заключить, что: во-первых - многие вопросы определения различных компетенций психолога на сегодняшний день остаются открытыми; во-вторых - социальная компетенция как профессионально-значимое качество психолога представляется ведущим компонентом его профессиональной компетентности.

B-третьих - основными компонентами социальной компетентности психолога являются: базовый; когнитивный компонент (интеллектуальные способности); социальный (специфика жизнедеятельности и взаимодействия с окружением); мотивационный (мотивы, интересы и т.д.); поведенческий (способность продуктивного поведения в конфликтных ситуациях, общие навыки поведения в социуме); эмоционально-волевой; рефлексивный; личностный компонент (индивидуально-психологические качества, такие как; эмпатийность, искренность, коммуникабельность и пр.) [2;3].

Анализ психологических исследований социальной компетентности психологов (В.И. Долгова, А.В. Карпов, Е.В. Мельник, Т.А. Шилова, А.В. Шорина) показал, что авторы чаще всего апеллируют к феноменам эмпатии и рефлексии, рассматривая их в качестве содержательного компонента социальной компетентности и как условие ее формирования. Способность к сопереживанию, погружению во внутренний мир другого человека, реализации деятельности рефлексивного характера представляется одним из ведущих показателей компетентности специалиста психолога, а также интегративным качеством, выступающим движущей силой эффективной реализации остальных компетенций. 


\section{Описание и анализ результатов исследования}

В исследовании особенностей рефлексивности и эмпатийности в структуре социальной компетентности психологов приняли участие две выборки: экспериментальная и контрольная. Экспериментальную выборку составили 85 педагогов-психологов в возрасте от 32 до 43 лет. Стаж профессиональной деятельности - от 3-х до 16-ти лет. Контрольную выборку - 85 учителей в возрасте от 30 до 46 лет. Базой исследования выступил Крымский республиканский институт постдипломного педагогического образования.

В качестве инструментария исследования применены: методика диагностики уровня развития рефлексивности А.В. Карпова, методика измерения уровня выраженности и направленности рефлексии, степени сформированности ауторефлексии и социорефлексии М. Гранта, методика «Диагностика уровня эмпатической компетенции» И.М. Юсупова.

Соотношение степени рефлексивности и эмпатийности в выборках по методикам измерения рефлексивности А.В. Карпова и М. Гранта, методике диагностики эмпатии И.М. Юсупова наглядно представлено в таблице 1. На основании данных, полученных при помощи «Методики диагностики уровня развития рефлексивности» А.В. Карпова выяснилось, что: высокоразвитой рефлексивностью обладают 75\% обследованных педагогов-психологов (показатель рефлексивности - в интервале от 140 до 171 балла); 25\% характеризует средний

Таблицуа 1.

\section{Степень выраженности рефлексии и эмпатии}

у педагогов-психологов и педагогов

\begin{tabular}{|c|c|c|c|c|c|c|c|c|}
\hline $\begin{array}{c}\text { Мето- } \\
\text { дики }\end{array}$ & \multicolumn{2}{|c|}{ Методика И.М. Юсупова } & \multicolumn{2}{|c|}{ Методика А.В. Карпова } & \multicolumn{2}{c|}{$\begin{array}{c}\text { Методика М. } \\
\text { Гранта }\end{array}$} \\
\hline $\begin{array}{c}\text { Уров- } \\
\text { ни }\end{array}$ & $\begin{array}{c}\text { Очень } \\
\text { высокий } \\
\text { уровень } \\
\text { эмпатии }\end{array}$ & $\begin{array}{c}\text { Вы- } \\
\text { сокий } \\
\text { эмовень } \\
\text { эмпаии }\end{array}$ & $\begin{array}{c}\text { Сред- } \\
\text { ний } \\
\text { уровень }\end{array}$ & $\begin{array}{c}\text { Высокий } \\
\text { уровень } \\
\text { рефлек- } \\
\text { сии }\end{array}$ & $\begin{array}{c}\text { Средний } \\
\text { уровень } \\
\text { рефлек- } \\
\text { сии }\end{array}$ & $\begin{array}{c}\text { Низкий } \\
\text { уровень } \\
\text { рефлек- } \\
\text { сии }\end{array}$ & $\begin{array}{c}\text { Ауто- } \\
\text { реф- } \\
\text { лексия }\end{array}$ & $\begin{array}{c}\text { Социо- } \\
\text { реф- } \\
\text { лексия }\end{array}$ \\
\hline ЭВ & $60 \%$ & $35 \%$ & $5 \%$ & $75 \%$ & $25 \%$ & - & $85 \%$ & $98 \%$ \\
\hline КВ & $20 \%$ & $25 \%$ & $55 \%$ & $47 \%$ & $38 \%$ & $15 \%$ & $55 \%$ & $70 \%$ \\
\hline
\end{tabular}

Примечание: * ЭВ - экспериментальная выборка; КВ - контрольная выборка 
уровень рефлексивности (от 114 до 139 баллов); психологов с низким уровнем рефлексивности (менее 113 баллов) в результате обследования не обнаружено.

В контрольной выборке учителей с высоким уровнем рефлексивности оказалось 47\% (от 140 до 171 балла); 38\% характеризует средний уровень рефлексивности (от 114 до 139 баллов); 15\% обладают низким уровнем рефлексивности (менее 113 баллов).

По данным диагностики рефлексивности по методике М. Гранта, средний, достаточный уровень ауторефлексии обнаружен у $85 \%$ педагогов-психологов, повышенный - у 25\%. В свою очередь, 55\% учителей отличает достаточный уровень ауторефлексии, повышенный - у 15\%. Высоким уровнем социорефлексии обладают 98\% педагогов-психологов и 70\% учителей.

В результате диагностики уровня эмпатической компетенции при помощи методики И.М. Юсупова выявлены следующие особенности проявления эмпатийности у педагогов-психологов: очень высокий уровень эмпатийности обнаружен у 60\%, высокий уровень - у 35\%, средний - у 5\%. В контрольной выборке обнаружен очень высокий уровень эмпатийности у 20\%, высокий уровень - у $25 \%$, средний - у $55 \%$.

В результате соотношения процентных долей двух выборок исследования, относительно выраженности рефлексии и эмпатии, по Т критерию Стьюдента, выяснилось, что педагоги-психологи достоверно отличаются от учителей большей эмпатийностью $(\mathrm{t}=257.2$, $\mathrm{p}<0,05)$ и рефлексивностью ( $\mathrm{t}=286.2$ и $\mathrm{t}=272.5$ при $\mathrm{p}<0,05)$,

Таким образом, педагоги-психологи, принявшие участие в исследовании, характеризуются большей чувствительностью к проблемам окружающих, великодушием, эмоциональной отзывчивостью, общительностью, коммуникативностью, заинтересованностью внутренним миром других людей. Они более склонны к компромиссам в конфликтных ситуациях, обладают развитой способностью к сочувствию, сопереживанию, по сравнению с учителями.

Итак, развитость рефлексивности и эмпатийных свойств у педагогов-психологов является одной из базовых компетенций психолога- 
профессионала. Личностный компонент социальной компетентности психолога определяется необходимостью проявлять эмпатию в консультировании, в психологическом сопровождении, представляет собой ведущие профессионально-значимые качества психолога, необходимые для успешного осуществления психологического взаимодействия с клиентом. В свою очередь, развитая рефлексивная деятельность психолога формирует его умение осуществлять рефлексивные акты, характеризуется устойчивой мотивацией самопознания и самосовершенствования в коммуникативной деятельности, способностью самостоятельно и эффективно решать проблемы в области профессиональной деятельности.

\section{Выводы}

1. Представляемые зарубежными и отечественными исследователями компетентностного подхода типологии и классификации компетенций различаются, с точки зрения терминологии, количества и приоритетности разных компетентностей или компетенций. Однако в состав большинства типологий включена социальная компетентность.

2. Социальная компетенция психолога является неотьемлемой составляющей его профессиональной компетентности, индивидуально-психологическим, интегративным качеством, формирующимся и проявляющимся по ходу решения специалистом различных задач, адекватных всему разнообразию социальных и профессиональных ситуаций.

3. К структурным компонентам социальных компетенций психологов относятся: когнитивный, социальный, мотивационный, поведенческий, эмоционально-волевой, рефлексивный, личностный.

4. Эмпатия и рефлексия представляются значимыми структурными и системообразующими элементами социальной компетентности психолога.

5. На основе знаний о специфике сформированности рефлексивности и эмпатийности у педагогов-психологов, представляется возможным осуществление последовательного формирующего воз- 
действия в рамках организации комплексной пропедевтической и тренинговой работы по развитию структурных компонентов социальной компетенции, организации рефлексивной образовательной среды, способствующей профессиональному самоопределению и самореализации специалиста в процессе постдипломного образования.

\section{Список литературы}

1. Зимняя И.А. Социально-профессиональная компетентность как целостный результат профессионального образования / И.А. Зимняя // Высшая школа: проблемы и перспективы: материалы 7-й Междунар. науч.-метод. конф., Минск, 1-2 ноября 2005 г. / Респ. ин-т высш.шк. Минск, 2005. С. 283-286.

2. Калиева А.Т. Развитие профессионально-важных качеств личности студентов-психологов в процессе профессиональной подготовки при дистанционной системе обучения при оценке 16-факторным опросником Р. Кеттелла /А.Т. Калиева //Альманах современной науки и образования. Тамбов: Грамота, 2008. № 10 (17): в 2-х ч. Ч. І. С. 67-69.

3. Каримова Л.Ш. Формирование социальной компетенции будущих педагогов-психологов: методические рекомендации для преподавателей вузов [Текст] / Л.Ш. Каримова. Казань: ТГГПУ, 2010. 65 с.

4. Федеральный государственный образовательный стандарт высшего профессионального образования по направлению подготовки 050400 «Психолого-педагогическое образование» (квалификация (степень) «Магистр»)/ [Электронный ресурс]. - Режим доступа: www.osu.ru

\section{References}

1. Zimnyaya I.A. Sotsial'no-professional'naya kompetentnost' kak tse-lostnyy rezul'tat professional'nogo obrazovaniya / I. A. Zimnyaya // Vysshaya shkola: problemy i perspektivy: materialy 7-y Mezhdunar. nauch.-metod. konf., Minsk, 1-2 noyabrya 2005 g. / Resp. in-t vyssh.shk. Minsk, 2005. S. 283-286.

2. Kalieva A.T. Razvitie professional'no-vazhnykh kachestv lichnosti studentov-psikhologov v protsesse professional'noy podgotovki pri dis- 
tan-tsionnoy sisteme obucheniya pri otsenke 16-faktornym oprosnikom R. Kettella / A.T. Kalieva // Al'manakh sovremennoy nauki i obrazovaniya. Tambov: Gramota, 2008. № 10 (17): v 2-kh ch. Ch. I. C. 67-69.

3. Karimova L.Sh. Formirovanie sotsial'noy kompetentsii budushchikh pedagogov-psikhologov: metodicheskie rekomendatsii dlya prepodavateley vuzov [Tekst] / L.Sh. Karimova. Kazan': TGGPU, 2010. 65 s.

4. Federal'nyy gosudarstvennyy obrazovatel'nyy standart vysshego professional'nogo obrazovaniya po napravleniyu podgotovki 050400 «Psikhologo-pedagogicheskoe obrazovanie» (kvalifikatsiya (stepen') «Magistr»)/ [Elektronnyy resurs]. Rezhim dostupa: www.osu.ru 